\title{
Reduction mammaplasty: Position of the nipple-areolar complex after long-term follow-up
}

\author{
Arnis Freiberg MD FRCSC FACS, Michele M Carr DDS MD \\ Division of Plastic Surgery, Toronto Hospital, Western Division, Department of Surgery, University of \\ Toronto, Toronto, Ontario
}

\begin{abstract}
A Freiberg, MM Carr. Reduction mammaplasty: Position of the nipple-areolar complex after long-term follow-up. Can J Plast Surg 1994;2(3):117-120. Permanence of the location of the nipple-areolar complex after reduction mammaplasty was examined in 59 women undergoing a modified Robbins technique. Average age was 35.9 years and follow-up ranged from 8.5 months to 14.5 years. Measurements were taken bilaterally by the same observer at each follow-up visit without regard for previous measurements. These included the sternal notch to nipple distance (SNN), areola to inframammary crease distance (AIM), and the vertical limb of the scar length ( VL). The first visit between one month and one year postoperatively was taken as the baseline to which later measurements were compared. With time, there was a trend to lengthening of the SNN and shortening of the VL, but all changes were less than $1 \mathrm{~cm}$ and none was statistically significant $(\mathrm{P}>0.05)$. Groups were divided on the basis of patient age, amount of tissue excised, preoperative breast type, and pregnancies since operation, and the same measurements compared. There were no statistically significant differences $(\mathrm{P}>0.05)$. These results support the authors' contention that nipple location remains stable following reduction mammaplasty.
\end{abstract}

Key Words: Nipple-areolar complex, Reduction mammaplasty

\begin{abstract}
Réduction mammaire : position du complexe mamelon-aréole après un suivi à long terme
RÉSUMÉ : La permanence de l'implantation du complexe mamelon-aréole après la réduction mammaire a fait l'objet d'une étude auprès de 59 femmes ayant subi une intervention avec technique de Robbins modifiée. L'âge moyen était de 35,9 ans et le suivi s'échelonnait de 8,5 mois à 14,5 ans. Les mesures ont été prises bilatéralement par le même observateur à chaque visite de suivi, sans égard aux mesures antérieures. Parmi ces mesures, notons la distance entre la fourchette sternale et le mamelon, la distance entre l'aréole et le pli inframammaire et la longueur de la cicatrice verticale. La première visite effectuée entre un mois et un an après l'opération a servi à noter les données de départ, auxquelles les mesures subséquentes ont été comparées. Avec le temps, on a noté une tendance à l'élongation de la distance entre la fourchette sternale et le mamelon et un raccourcissement de la cicatrice, mais tous les changements étaient inférieurs à $1 \mathrm{~cm}$, et aucun n'était statistiquement significatif ( $\mathrm{P}>0,05)$. Les groupes ont été divisés sur la base de l'âge, de la quantité de tissu excisée, du type de sein en préopératoire, des grossesses depuis l'opération, et les mesures équivalentes ont été comparées. Aucune différence statistiquement significative n'a été notée $(P>0,05)$. Ces résultats appuient l'hypothèse de l'auteur selon laquelle la localisation du mamelon demeure stable après une réduction mammaire.
\end{abstract}

S rgical reduction of hypertrophied breasts was first described in antiquity (1) but only in the last few decades have a multitude of different techniques been applied, assessed, revised and discarded.

The purpose of reduction mammaplasty is to correct a deformity that patients regard as grotesque, and to reduce the weight of hypertrophied breasts in order to improve comfort. An ideal technique would maintain sensation and function, minimize scarring, and give a lasting result (2-4). There is debate over how these ends are best achieved in different

Presented at the Canadian Society of Plastic Surgeons Annual Meeting May 1992, London, Ontario.

Correspondence and reprints: Dr A Freiberg, Edith Cavell 4-034, Toronto

Hospital, Western Division, 399 Bathurst Street, Toronto, Ontario,

Canada M5T 2S8. Telephone (416) 369-5691; Fax (416) 369-5297. clinical situations. Although much has been written about preservation of sensation and aesthetics, there is very little scientific literature about permanence of surgical results $(5,6)$. This study examines long-term maintenance of results following an inferior pedicle technique of reduction mammaplasty.

\section{METHOD}

To minimize high-riding nipples, the original Robbins reduction mammaplasty technique was modified by leaving the keyhole portion of the Wise pattern uncut until after suturing the $\mathrm{T}$ portion. Then the operating table was tilted upward and the breast apex, a spot 4 to $4.5 \mathrm{~cm}$ from the inframammary fold, was located and the nipple positioned there. Female patients who underwent this procedure between 1977 and 1991 and had at least two postoperative visits after the first month were included in the study. At each 


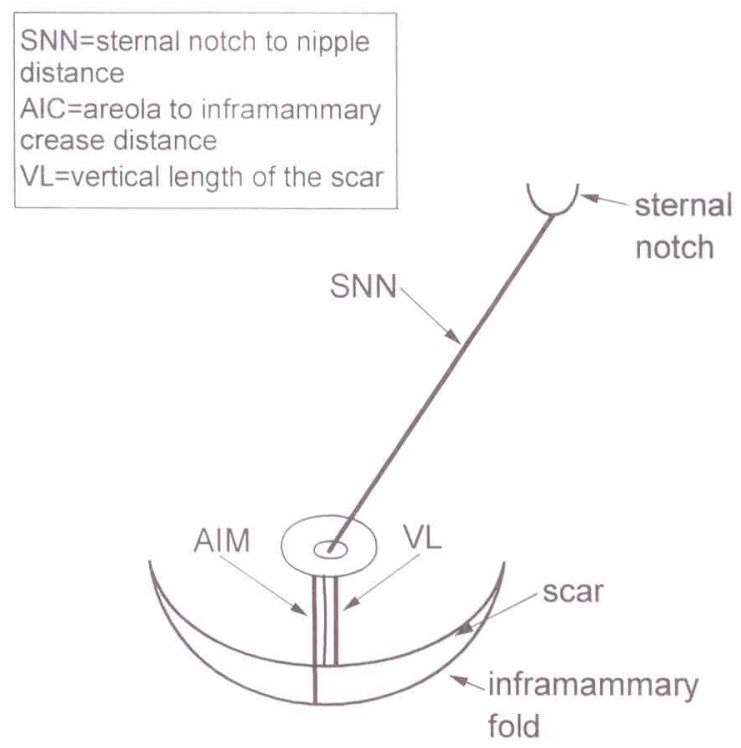

Figure 1) Diagram outlining the distances measured on each operated breast

\section{TABLE 1: Breast type}

\begin{tabular}{|c|c|c|c|}
\hline Type & $\begin{array}{l}\text { Clinical } \\
\text { appearance }\end{array}$ & Interpretation & Usual patient \\
\hline 1 & Full above nipple & $\begin{array}{l}\text { Hypertrophy with } \\
\text { normal support }\end{array}$ & Young nulliparous \\
\hline 2 & $\begin{array}{l}\text { Little/no bulge } \\
\text { above nipple }\end{array}$ & $\begin{array}{l}\text { Hypertrophy with } \\
\text { lax support }\end{array}$ & $\begin{array}{l}\text { Older multiparous, } \\
\text { weight loss }\end{array}$ \\
\hline 3 & $\begin{array}{l}\text { Ptosis with flat } \\
\text { contour above } \\
\text { nipple }\end{array}$ & $\begin{array}{l}\text { Normal bulk with } \\
\text { lax support }\end{array}$ & Older multiparous \\
\hline
\end{tabular}

follow-up visit photographs were taken and measurements made with a flexible cloth tape measure. With the patient in a sitting position, the distance between the sternal notch and the centre of the nipple (SNN) was measured in centimetres. Then with the patient lying supine the distance between the lower edge of the areola and the inframammary crease (AIC), and the length of the vertical limb of the scar $(\mathrm{VL})$ were measured in the same way (Figure 1). All measurements were bilateral. All were done by the same investigator without knowledge of previous measurements. Eight patients were remeasured to obtain an assessment of reliability. The first visit between one month and one year postoperatively was taken as the baseline value for each individual and further measurements were compared to this.

Patients were asked to complete questionnaires at every visit, which included their present weight and whether they had undergone any pregnancies since their surgery.

Perioperative data included age at operation, weight, breast type and amount of breast tissue excised. Breast type was classified into three categories (3) (Table 1).

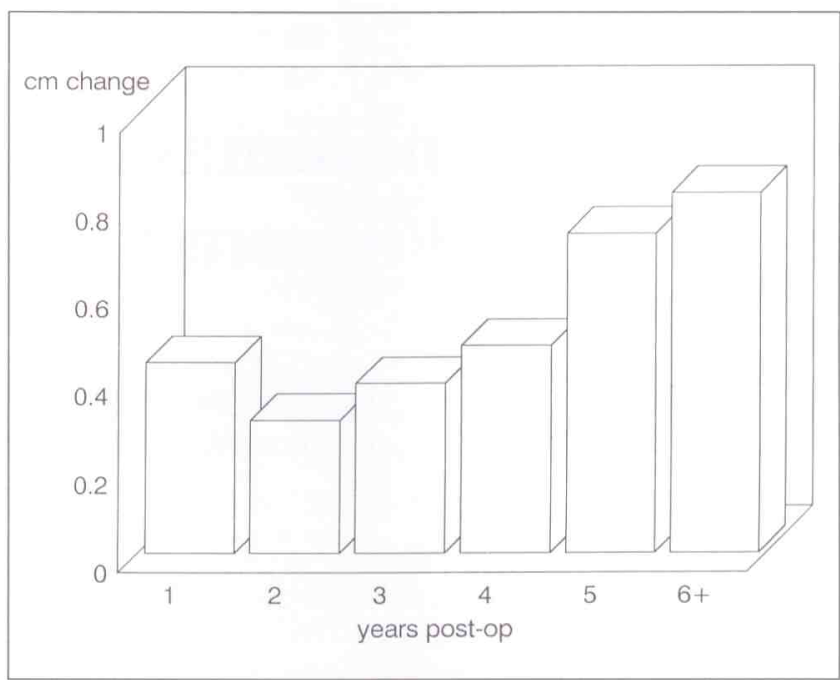

Figure 2) Sternal notch to nipple distance versus number of years postoperatively. Bars represent the total length in centimetres that this distance increased since operation. All groups averaged less than $1 \mathrm{~cm}$

\section{RESULTS}

There were 91 observations on 59 patients, with follow-up averaging 2.9 years (range 8.5 months to 14.5 years). Average age at operation was 35.9 years ranging from 12 to 71 years. Average amount excised (combined) was $1381 \mathrm{~g}$. Fifty-two percent had type 2 breasts, $45 \%$ were type 1 and $3 \%$ were type 3 . There were six patients who had undergone new pregnancies during the study period. Change in centimetres was calculated for each measurement as shown in Table 2. Average change was less than $1 \mathrm{~cm}$ for each parameter.

Left and right sides were compared showing no significant difference $(\mathrm{P}<0.005)$ and good correlation.

Pearson coefficients of correlation were calculated for all the distances for the eight remeasured cases and all were greater than 0.9 .

Data were grouped into one year follow-up intervals, which resulted in six groups being formed, the last of which included all patients with follow-up of more than five years (Figures 2, 3 and 4). Age, amount of tissue excised and each individual measurement was compared with a Student's $t$-test and there were no statistically significant differences among any of the groups. Kruskal-Wallis tests were used to compare breast type between all the groups and again there were no statistically significant differences. There was a trend toward lengthening of the SNN and shortening of the VL with time.

The influence of age at operation, pregnancy after reduction, breast type and weight change on the measured variables was also examined.

Two groups were selected based on the age at operation: one group comprised all those younger than 25 years $(n=36)$ and the other included all patients older than $49(n=20)$. The age group clustered around the mean (between 25 and 49 years old) was discarded in order to compare the very young to the older patients. Change in measurements were compared with $t$-tests and there were no demonstrable differences. 


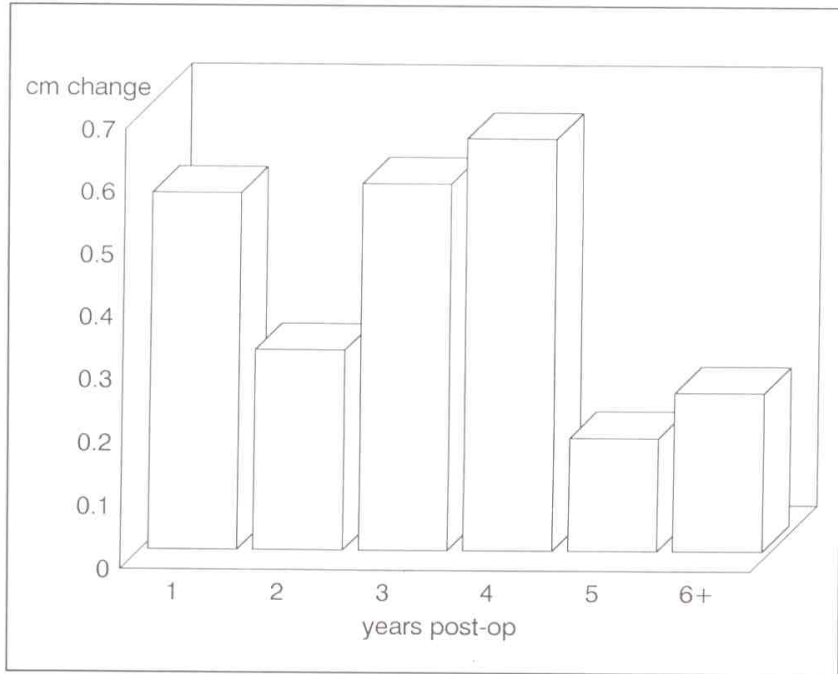

Figure 3) Areola to inframammary crease distance versus number of years postoperatively. Again, all groups averaged less than $1 \mathrm{~cm}$ increase since operation

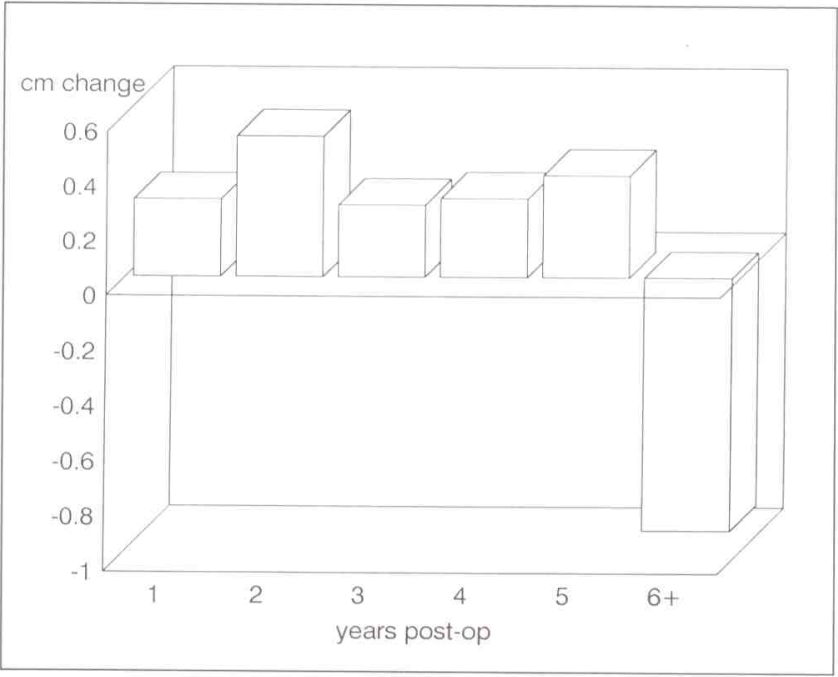

Figure 4) Vertical length of the scar versus number of years postoperatively. There was generally less than $0.5 \mathrm{~cm}$ increase in this distance regardless of the number of years elapsed since surgery. After six years, this distance apparently shrank, consistent with scar contracture

Data was divided according to pre-operative breast type (one versus two) and the variables compared. No statistical differences were seen. There were too few type 3 patients to compare meaningfully.

The effect of pregnancy after reduction was difficult to assess since there were only seven pregnancies in six subjects. Although there was a trend to greater change in variables in these women, this was not statistically significant.

The effect of weight change was also difficult to assess because weights were collected from patient reports. Thirteen patients had weight change recorded which ranged from $7 \mathrm{~kg}$ lost to $12 \mathrm{~kg}$ gained. Those with weight gain were compared to those with weight loss and there was no demonstrable difference in dimensional change.
TABLE 2: Mean change in centimetres for each distance (Mean years follow-up $=2.95, \mathrm{n}=91$ )

\begin{tabular}{lcc} 
Distance & Mean change $(\mathrm{cm})$ & Standard deviation \\
\hline SNN & 0.385 & 0.8896 \\
AIC & 0.526 & 0.7473 \\
VL & 0.25 & 0.7984 \\
\hline
\end{tabular}

AIC Areola to inframammary crease distance; SNN Sternal notch to nipple distance; VL Vertical length of the scar

\section{DISCUSSION}

The ideal method of monitoring post reduction mammaplasty results has yet to be devised. In 1988 Meredith and Montandon (5) used visual analog scales to examine 35 cases after reduction mammaplasty with a variety of techniques. These scales included symmetry, width of scars, and nippleareolar complex (NAC) position and colour. They found that three of the five cases where the nipple was too high had been reduced with an inferior pedicle technique. Although this gives a subjective picture of the surgical result at a certain time it does not objectively quantify results or changes.

Reus and Mathes (6) used an objective set of measurements to look at NAC position with time following reduction mammaplasty with the inferior pedicle technique. In a group of 22 patients they saw the distance between the nipple and the inframammary fold increase and explained this as sagging of the breast parenchyma. They also felt that the distance between the clavicle and the nipple remained fairly constant, resulting in an apparent superior migration of the nipple (6). This trend is also accepted by other surgeons to occur following inferior pedicle, horizontal and vertical bipedicle and free nipple graft techniques (7-11).

What are the natural ageing changes in the breast? Hormonal changes result in alterations of the breast volume (12). Stretching of the skin is thought to occur both above and below the nipple (6). Thus the natural ageing of the unoperated breast results in some degree of ptosis. Therefore, the superior migration of the nipple described following reduction mammaplasty is not a natural effect of ageing.

NAC placement is vital to the final post-reduction mammaplasty appearance and many techniques have been described. Strombeck (13) first suggested that the NAC should be positioned over the inframammary crease which should coincide with the apex of the breast mound. If reduction is not carried out carefully these two landmarks may vary. The operative technique used for these patients placed greater importance on the apex of the mound, ensuring that the NAC was placed there. Our study of 91 follow-up examinations included a wide range of patient ages, size of reduction, and post-operative changes (ie, weight and pregnancy). Careful measurement of NAC position showed very little movement over several years.

We conclude that in a modified Robbins reduction mammaplasty, with NAC position dictated by the location of the apex of the breast mound after the initial stages of the operation, stability of the vertical position of the NAC can be assured for several years. 


\section{REFERENCES}

1. Letterman G, Schurter M. Will Durston's "mammaplasty". Plast Reconstr Surg 1974;53:48.

2. Robbins TH. A reduction mammaplasty with the areola-nipple based on an inferior dermal pedicle. Plast Reconstr Surg 1977;59:64.

3. Freiberg A, Boyd JB. Reduction mammaplasty: A comparison between the Robbins and Pontes techniques. Plast Reconstr Surg 1986;78:773.

4. Pompeo de Pina, D. Mammaplasty: Shape, volume, and scar size. Aesth Plast Surg 1990;14:27.

5. Meredith $\mathrm{P}$, Montandon D. Résultats à long terme de 68 cas de réductions mammaires opérés dans un service de chirurgie universitaire. Helv Chir Acta 1988;55:887.

6. Reus WF, Mathes SJ. Preservation of projection after reduction mammaplasty: Long-term follow-up of the inferior pedicle technique. Plast Reconstr Surg 1988;82:644.

7. O'Keeffe PJ. Draftsmanship for reduction mammaplasty. Annals Plast Surg 1983;10:467.

8. Hoffman S. Recurrent deformities following reduction mammaplasty. Aesth Plast Surg 1986;78:55.

9. Elsahy NI. Correction of abnormally high nipples after reduction mammaplasty. Aesth Plast Surg 1990;14:21.

10. Millard DR, Mullin WR, LeSavov MA. Secondary correction of the too-high areola and nipple after a mammaplasty. Plast Reconstr Surg 1976;58:568.

11. Dinner MI, Chait L. Preventing the high-riding nipple after McKissock breast reductions. Plast Reconstr Surg 1976;59:330.

12. Bland KI, Copeland FM, eds. The Breast: Comprehensive Management of Benign and Malignant Diseases. Philadelphia: WB Saunders, 1991.

13. Strombeck JO. Reduction mammaplasty. Surg Clin North Am 1971;51:453. 